\title{
FORMULASI SOFT CHEWY COOKIES BEBAS GLUTEN DAN KASEIN BERBASIS KOMBINASI MOCAF DAN TEPUNG MILLET PUTIH UNTUK ANAK AUTISM SPECTRUM DISORDER
}

\author{
Free Gluten and Free Casein Soft Chewy Cookies Formulation with Combination of MOCAF \\ and White Millet Flour Based for Children with Autism Spectrum Disorder \\ Kirana Dwiyanti Prasetyo ${ }^{*}$, Dominikus Raditya Atmaka ${ }^{2}$ \\ 1 Program Studi S1 Gizi, Fakultas Kesehatan Masyarakat, Universitas Airlangga, Surabaya, Indonesia \\ 2 Departemen Gizi Kesehatan, Fakultas Kesehatan Masyarakat, Universitas Airlangga, Surabaya, Indonesia \\ *E-mail: kiranadwiyanti@gmail.com
}

\begin{abstract}
ABSTRAK
Anak dengan Autism Spectrum Disorder (ASD) memiliki kondisi khusus yang menyebabkan anak ASD harus menjalani diet bebas gluten dan kasein. Kasein banyak terkandung pada produk susu sapi dan olahannya yang juga merupakan sumber kalsium. Kondisi tersebut menyebabkan anak ASD cenderung memiliki kepadatan tulang yang lebih rendah dibandingkan anak tanpa ASD. Modified Cassava Flour (MOCAF) dan tepung millet putih merupakan bahan makanan bebas gluten yang memiliki kandungan kalsium tinggi yang diharapkan dapat meningkatkan nilai gizi kalsium pada soft chewy cookies. Penelitian ini bertujuan untuk mengetahui pengaruh kombinasi MOCAF dan tepung millet putih terhadap daya terima dan nilai gizi soft chewy cookies bebas gluten dan kasein. Penelitian ini merupakan eksperimental murni dengan rancangan percobaan Rancang Acak Lengkap. Penelitian ini menggunakan panelis tidak terlatih yang meliputi 25 anak ASD (7-11 tahun) dan 25 orang tua atau wali anak. Terdapat 4 formula pada penelitian ini yang terdiri dari 1 formula kontrol (F0) yang berbasis 100\% tepung terigu, dan 4 formula perlakuan yang merupakan kombinasi MOCAF dan tepung millet putih dengan persentase perbandingan kombinasi F1 (0\% : 100\%); F2 (50\%:50\%); dan F3 (75\%:25\%). Hasil uji statistik Kruskall Wallis menunjukkan terdapat perbedaan signifikan tingkat kesukaan pada aspek warna, aroma, tekstur, dan rasa antar F0, F1, F2, dan F3. Perhitungan daya terima dan nilai gizi didapatkan F3 sebagai formula terbaik. Pada setiap porsi soft chewy cookies F3 (60 gram) mengandung 176,4 mg kalsium yang memenuhi 18\% kecukupan kalsium untuk anak 7-11 tahun. Soft chewy cookies bebas gluten dan bebas kasein kombinasi MOCAF dan tepung millet putih F3 layak sebagai jajanan alternatif anak ASD.
\end{abstract}

Kata kunci: soft chewy cookies, bebas gluten, bebas kasein, MOCAF, tepung millet putih, kalsium

\section{ABSTRACT}

Children with Autism Spectrum Disorder (ASD) have to eat a gluten-free casein-free diet due to their special condition. Casein is protein that contained in milk and milk-based product which are source of calcium. Their special condition make children with ASD have a low bone-mass than other children. Modified Cassava Flour (MOCAF) and white millet flour are free gluten food sources which have rich calcium that is needed to increase nutrient quality in soft chewy cookies. This study was aimed to determine the effect of MOCAF flour and white millet flour combination on acceptability and nutritional value of free gluten and free casein soft chewy cookies. This study was true experimental study with complete randomized design. This study used un-trained panelist including ASD children(7-11 years old (25 panelists) and their parents (25 panelists). There were 4 formulas in this study consisted of 1 control formula (F0) based on 100\% wheat flour, and 4 treatment formulas which were combination of MOCAF flour and white millet flour with a percentage ratio of combination F1 (0\%:100\%); F2 (50\%:50\%); and F3 (75\%:25\%). Kruskal Wallis statistical test results showed there were significant differences of aroma, color, texture, and taste between each formula. Result of acceptability and nutritional value showed F3 as the best formula. Each $60 \mathrm{~g}$ soft chewy cookies F3 contains 176,4 mg of calcium which fulfill 18\% of calcium adequacy for 7-11 year old children. Gluten-free casein-free soft chewy cookies with combination of MOCAF and white millet flour are suitable as an alternative snack for ASD children.

Keywords: soft chewy cookies, free gluten, free casein, MOCAF, white millet flour, calcium 


\section{PENDAHULUAN}

World Health Organization (WHO) melaporkan bahwa 1 dari 160 anak di dunia mengalami autisme (WHO, 2019). Prevalensi autis pada anak di Amerika Serikat mengalami peningkatan yang sebelumnya 1 dari 150 anak menjadi pada tahun 2000 (Maenner dkk., 2020) menjadi 1 dari 54 anak pada tahun 2016 (CDC, 2020). Indonesia sendiri sampai saat ini belum memiliki data statistik jumlah penyandang autis secara resmi (Kemenkes, 2016)

Anak dengan Autism Spectrum Disorder (ASD) memiliki pantangan untuk mengonsumsi makanan yang gluten dan kasein. Hal tersebut disebabkan karena terdapat gangguan pencernaan (hipermeabilitas usus) yang menyebabkan gluten dan kasein yang tidak terserap dapat mempengaruhi sistem saraf pusat (Pratiwi, 2014). Izzah dkk. (2020) menyebutkan bahwa terdapat perbedaan gejala terutama pada gangguan perilaku yang signifikan pada anak autis yang diet bebas gluten dan kasein (diet GFCF) dengan yang tidak diet. Gejala pada anak autis yang diet bebas gluten dan kasein lebih ringan daripada yang tidak diet.

Anak dengan ASD yang mematuhi diet Gluten Free Casein Free (GFCF) cenderung mengalami defisiensi kalsium dan memiliki kepadatan tulang yang lebih rendah dibandingkan anak tanpa ASD karena pembatasan konsumsi protein kasein yang banyak terdapat pada susu dan olahannya (Amalia, 2014). Penelitian yang dilakukan oleh Moore dkk (2012) menunjukkan bahwa asupan kalsium pada anak ASD hanya 65\% dari Dietary Reference Intake (DRI).

Indonesia merupakan negara yang kaya akan sumber bahan pangan salah satunya adalah serealia. Salah satu bahan pangan serealia yang banyak tersedia di Indonesia adalah millet putih. Selama ini, di Indonesia biji millet hanya digunakan sebagai bahan pakan burung. Di Afrika, Rusia, dan negara-negara maju lainnya, millet sudah banyak digunakan sebagai bahan pangan untuk manusia. (Besari, 2017). Millet adalah sejenis sereal berbiji kecil yang pernah menjadi makanan pokok di Asia Timur. Millet termasuk tanaman ekonomi minor namun memiliki nilai kandungan gizi yang mirip dengan tanaman pangan lainnya seperti padi, jagung, gandung, dan tanaman biji-bijian lainnya (Subandoro, 2013).
Hasil analisis kandungan kalsium, magnesium, dan vitamin B6 pada millet putih dalam bentuk tepung di Laboratorium Analisis Gizi FKM Universitas Airlangga dengan No. Sampel 045/LabGizi/2020 menunjukkan bahwa kalsium yang terkandung adalah sebesar $1170 \mathrm{mg} / 100 \mathrm{~g}$, magnesium 25 $\mathrm{mg} / 100 \mathrm{~g}$ dan vitamin B6 0,42 mg/100 g.

Prabowo (2010) melakukan kajian sifat fisikokimia tepung millet kuning/putih dan tepung millet merah yang dinilai layak dijadikan tepung bebas gluten pengganti tepung terigu. Tepung bebas gluten lainnya yang telah banyak digunakan adalah MOCAF. Namun, MOCAF memiliki kekurangan yaitu kalsium yang belum dapat memenuhi kebutuhan anak ASD apabila dibentuk produk selingan, sehingga tepung millet dapat menjadi bahan yang dapat dikombinasikan dengan MOCAF untuk meningkatkan nilai gizi pada suatu produk.

Cookies dipilih menjadi produk berdasarkan penelitian oleh Camelia (2019) karena anak ASD cenderung meminta jajanan ringan. Cookies dinilai menjadi salah satu jajanan ringan yang dapat dengan mudah dikonsumsi kapanpun dan dimanapun. Cookies merupakan produk yang berbahan dasar utama tepung terigu yang memiliki sifat fisikokimia mirip dengan tepung millet putih dan MOCAF. Menurut Demand dkk (2016), anak ASD memiliki gangguan mengunyah sehingga diperlukan cookies dengan tekstur yang lebih lembut. Tekstur yang lembut terdapat pada jenis soft chewy cookies. Resep dasar yang digunakan adalah resep dari Julia (2013) dengan mengganti chocolate chip dengan wijen karena anak ASD memiliki pantangan untuk mengonsumsi cokelat.

Penelitian ini bertujuan untuk mencari formula soft chewy cookies bebas gluten dan kasein yang dapat diterima oleh anak ASD dengan memanfaatkan MOCAF yang dikombinasikan tepung millet putih untuk meningkatkan asupan kalsium yang baik bagi anak ASD.

\section{METODE}

Penelitian ini merupakan penelitian eksperimental murni (true experimental) dengan desain Rancang Acak Lengkap (RAL). Terdapat 4 formula yaitu 1 formula kontrol (F0) dan formula perlakuan (F1, F2, dan F3). Pada formula F0 
menggunakan bahan dasar tepung terigu merk Segitiga Biru dengan kandungan protein 10 g/100g. Formula F1, F2, F3 tidak menggunakan tepung terigu namun menggunakan kombinasi MOCAF merk ladang lima dengan kandungan protein $1,2 \mathrm{~g} / 100 \mathrm{~g}$ dikombinasikan tepung millet putih dengan kandungan protein $8 \mathrm{~g} / 100$ g. Penelitian dilakukan pada bulan Juni 2020. Pembuatan soft chewy cookies dilakukan di rumah peneliti sehubungan dengan pandemi COVID-19, sedangkan uji organoleptik dilakukan di SLB Autis Mutiara Hati Surabaya dengan memperhatikan protokol kesehatan, dan uji kadar kalsium di Laboratorium Analisis Gizi Fakultas Kesehatan Masyarakat Universitas Airlangga.

Panelis pada penelitian ini adalah panelis tidak terlatih yang terdiri dari anak ASD (25 anak) sebagai panelis semu beserta orang tua atau wali (25 orang) sebagai panelis sejati. Kriteria inklusi dalam penelitian ini adalah anak ASD berusia 7-11 tahun bersama 1 orang tua atau wali. Kriteria ekslusi dalam penelitian ini adalah memiliki alergi terhadap telur.

Penilaian yang dilakukan pada penelitian ini terdiri dari penilaian daya terima serta perhitungan kadar kalsium. Penilaian daya terima meliputi aspek warna, aroma, tekstur, dan rasa dilakukan oleh panelis orang tua atau wali pada formula F0, F1, F2, dan F3 menggunakan angket uji kesukaan dengan skala data ordinal dengan 4 skala penilaian

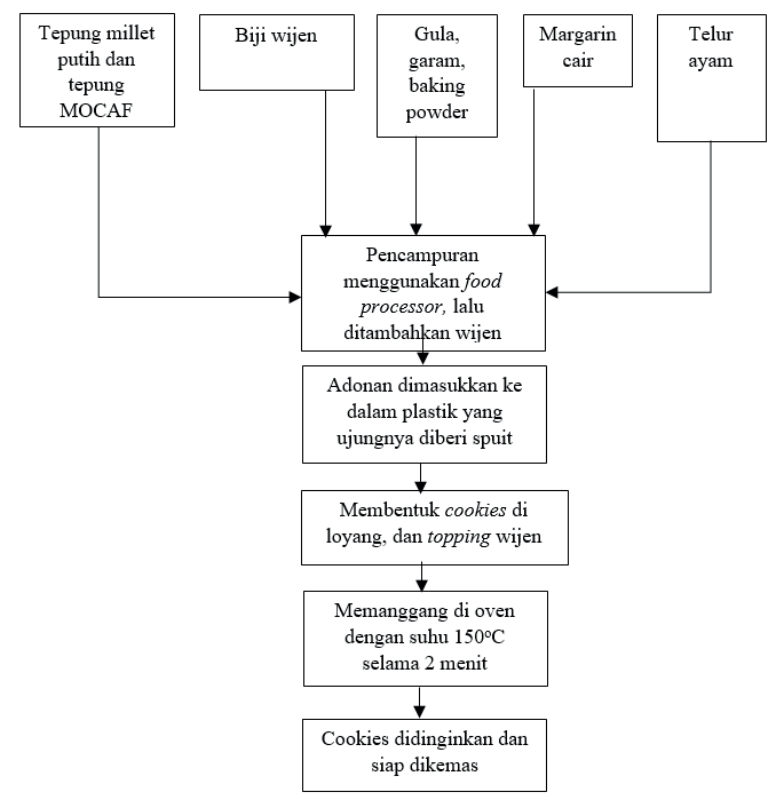

Gambar 1. Alur Pembuatan Soft Chewy Cookies yaitu nilai (1) untuk sangat tidak suka, (2) untuk tidak suka, (3) untuk suka, dan (4) untuk sangat suka.

Penilaian daya terima pada anak hanya dilakukan pada formula F1, F2, dan F3 karena formula F0 berbasis tepung terigu yang mengandung gluten dan merupakan pantangan bagi anak ASD.

Penilaian daya terima pada anak mengacu pada Hendrayati dkk. (2020) dengan menggunakan metode food weighting dengan rumus

$$
\text { Daya Terima }=\frac{\text { Berat awal-Berat sisa }}{\text { Berat awal }} \times 100 \%
$$

Penilaian pada anak menggunakan skala data ordinal meliputi penilaian bagian biskuit yang dihabiskan yaitu (1) anak tidak mau atau kukis yang dicicipi $<30 \%$; (2) anak mau, kukis dicicipi 30-80\% ; (3) anak mau, kukis dimakan $80-100 \%$.

Penilaian dilakukan dalam 2 sesi yaitu sesi pertama untuk panelis anak dan sesi kedua untuk panelis orang tua. Pada sesi pertama dibantu oleh orang tua atau wali dalam memberikan makanan kepada panelis anak. Perhitungan serta pengisian kuesioner dilakukan oleh enumerator. Sesi kedua dilakukan oleh masing-masing orang tua atau wali. Tiap formula disajikan satu per satu dalam waktu 10 menit dengan kode berupa perpaduan angka dan huruf tanpa melambangkan suatu makna tertentu untuk menghindari adanya pemilihan kesukaan berdasarkan kesan pertama. Panelis diminta untuk meminum air putih guna menetralkan rasa pada setiap pergantian sampel formula.

Tabel 1. Formula Soft Chewy Cookies

\begin{tabular}{lcccc}
\hline \multicolumn{1}{c}{ Bahan (g) } & F0 & F1 & F2 & F3 \\
\hline Tepung Terigu & 270 & 0 & 0 & 0 \\
MOCAF & 0 & 0 & 70 & 200 \\
Tepung Millet Putih & 0 & 270 & 200 & 70 \\
Gula Pasir & 100 & 100 & 100 & 100 \\
Gula Palm & 220 & 220 & 220 & 220 \\
Telur & 70 & 70 & 70 & 70 \\
Margarin & 226 & 226 & 226 & 226 \\
Garam & 1 & 1 & 1 & 1 \\
Chocolate Chip & 120 & 0 & 0 & 0 \\
Wijen & 0 & 120 & 120 & 120 \\
\hline Total (g) & 1008 & 1008 & 1008 & 1008 \\
\hline
\end{tabular}


Uji daya terima diolah dengan SPSS menggunakan Uji Kruskal-Wallis $(\alpha=0,05)$ untuk mengetahui perbedaan daya terima soft chewy cookies kombinasi MOCAF dan tepung millet putih. Uji lanjut Mann Whitney $(\alpha=0,05)$ digunakan untuk mengetahui signifikansi perbedaan antar formula. Formula terbaik dari segi daya terima dan nilai gizi TKPI, selanjutnya akan diuji kadar kalsium menggunakan metode Absorption Atomic Spectrometer (AAS) dengan alat ThermoScientific iCE 3000 dengan panjang gelombang $422,7 \mathrm{~nm}$.

Penelitian ini telah mendapatkan persetujuan Komisi Etik Penelitian Kesehatan, Fakultas Keperawatan Universitas Airlangga Surabaya No. 1978-KEPK.

\section{HASIL DAN PEMBAHASAN}

\section{Daya Terima Orang tua atau Wali}

Daya terima orang tua merupakan hal yang penting untuk dinilai. Penerimaan orang tua berkaitan dengan pemilihan makan pada anak ASD. Barbier (2015) menyatakan bahwa orang tua yang berfokus pada peningkatan kebiasaan makan anak ASD, akan mendorong anak untuk mencoba makanan baru. Peran orang tua juga dapat mempengaruhi pemilihan makanan anak ASD. Pratiwi dan Dieny (2014) juga menyebutkan bahwa peran orang tua (ibu) sebagai pemberi makan kepada anak cukup menentukan kesukaan atau kebiasaan makan anak sehingga pendapat orang tua dalam penilaian daya terima perlu dilakukan. Tabel 2. menunjukkan rekapitulasi rerata formula pada setiap parameter daya terima orang tua atau wali anak ASD yang menunjukkan bahwa formula F0 merupakan formulasi kontrol dengan mean paling tinggi dalam aspek warna, aroma, tekstur, dan rasa.
Penilaian terhadap warna menunjukkan bahwa F0 $(3,04)$ adalah warna yang paling disukai oleh panelis yaitu cokelat keemasan. Formula perlakuan yang memiliki nilai kesukaan paling tinggi adalah F3 $(2,84)$ sedangkan paling rendah adalah F1 $(2,36)$. Formula F1 memiliki warna yang lebih gelap sehingga kurang disukai oleh panelis. Warna gelap pada F1 disebabkan oleh komposisi tepung millet yang digunakan adalah $100 \%$, sedangkan pada F3 komposisi tepung millet sebesar 25\% dan dikombinasikan dengan MOCAF sebesar $75 \%$. Tepung millet memiliki kandungan protein yang lebih tinggi $(8 \mathrm{~g} / 100 \mathrm{~g})$ dibandingkan MOCAF $(1,2 \mathrm{~g} / 100 \mathrm{~g})$, sehingga soft chewy cookies dengan kandungan tepung millet yang lebih tinggi lebih mudah mengalami reaksi mailard dan menghasilkan warna lebih gelap. Hal tersebut sejalan dengan pernyataan Simpson (2012) yang menyebutkan bahwa akan terjadi reaksi mailard yaitu pencokelatan yang terjadi ketika bahan makanan dengan protein tinggi mereduksi gula dengan suhu di atas $50^{\circ} \mathrm{C}$ yang merupakan reaksi non enzimatik dan menghasilkan warna coklat pada makanan.

Penilaian karakteristik aroma soft chewy cookies didasarkan pada SNI 2973-2011 tentang biskuit dan kukis yaitu beraroma harum dan tidak tercium bau asing yang menimbulkan rasa tidak nyaman. Tabel 2 menunjukkan bahwa aroma yang paling disukai oleh panelis adalah pada formula F0 dengan rata-rata penilaian 3,52 . Formula perlakuan yang memiliki aroma yang paling disuka oleh panelis adalah F3 dengan rata-rata penilaian 2,84. Formula perlakuan yang memiliki nilai paling rendah adalah $\mathrm{F} 1$ dengan rata-rata penilaian 2,40 dikarenakan adanya aroma millet putih yang lebih menyengat dibandingkan formula lainnya menurut panelis. Formula F1 dengan bahan dasar

Tabel 2. Rekapitulasi Distribusi Tingkat Kesukaan Panelis Orang Tua atau Wali Anak ASD

\begin{tabular}{|c|c|c|c|c|c|c|}
\hline \multirow{2}{*}{ Parameter } & \multicolumn{4}{|c|}{ Formula } & \multirow{2}{*}{ Std. Deviation } & \multirow{2}{*}{ p-value } \\
\hline & F0 & F1 & F2 & F3 & & \\
\hline Warna & $3,04^{a, b}$ & $2,36^{a, c}$ & $2,64^{b}$ & $2,84^{c}$ & 0,637 & $0,001 *$ \\
\hline Aroma & $2,36^{a, b, c}$ & $2,40^{a}$ & $2,80^{b}$ & $2,84^{c}$ & 0,795 & $0,001 *$ \\
\hline Tekstur & $2,32^{a, b}$ & $2,48^{a, c}$ & $2,68^{b}$ & $2,96^{c}$ & 0,625 & $0,001 *$ \\
\hline Rasa & $3,84^{a, b, c}$ & $2,60^{a}$ & $2,96^{b}$ & $3,24^{c}$ & 0,838 & $0,001 *$ \\
\hline
\end{tabular}

Keterangan:

Angka yang diikuti dengan huruf yang berada pada paremeter yang sama menunjukkan adanya perbedaan signifikan menurut uji Mann-Whitney $(\mathrm{p}<0,05)$ 
$100 \%$ tepung millet putih memiliki aroma khas millet yang lebih menyengat. Aroma yang khas tersebut dikarenakan tepung millet putih memiliki kandungan asam amino yaitu asam glutamat, lisin, asam aspartat, leusin, dan alanine yang bereaksi dengan gula sehingga memberikan aroma khas setelah proses pemanggangan pada suhu 190 $210{ }^{\circ} \mathrm{C}$ (Simpson, 2012).

Penilaian terhadap tekstur pada Tabel 2 menunjukkan bahwa formula kontrol F0 memiliki rata-rata nilai kesukaan tertinggi yaitu 3,32. Formula perlakuan yang memiliki nilai kesukaan tekstur tertinggi adalah F3 dengan rata-rata penilaian 2,96 . Formula perlakuan yang memiliki nilai terendah adalah $\mathrm{F} 1$ dengan rata-rata penilaian 2,48 yang disebabkan oleh tekstur pada formula F1 terlalu keras dan crumbling menurut panelis. Formula F1 berbahan dasar 100\% tepung millet putih. Tepung millet putih memiliki kandungan protein yang lebih tinggi $(8,3 \mathrm{~g} / 100 \mathrm{~g})$ dibandingkan MOCAF (1,2 g/100 g). Andarwulan dkk (2011) yang menyebutkan bahwa kerenyahan cookies dipengaruhi oleh kandungan protein, amilosa dan amilopektin. Protein mempunyai sifat hidrofilik yaitu mempunyai daya serap air yang tinggi. Sehingga, kukis dengan proporsi tepung millet yang lebih tinggi cenderung memiliki sifat yang lebih keras dan crumbling dibandingkan kukis dengan proporsi MOCAF yang lebih tinggi.

Penilaian terhadap rasa yang dihasilkan soft chewy cookies pada tabel 2 menunjukkan bahwa penilaian tertinggi terdapat pada formula kontrol (F0) dengan rata-rata penilaian kesukaan 3,84. Formula perlakuan yang memiliki nilai kesukaan tertinggi pada aspek rasa adalah formula F3 dengan rata-rata penilaian 3,24 , sedangkan penilaian rasa terendah terdapat pada F1. Formula F0 dengan bahan dasar $100 \%$ tepung terigu merupakan formula yang paling disukai karena tidak memiliki rasa yang asing bagi panelis. Hal ini sejalan dengan penelitian yang dilakukan oleh Gobel dkk (2016) yang menunjukkan bahwa cookies dengan bahan dasar $100 \%$ tepung terigu lebih disukai daripada cookies dengan substitusi dan campuran tepung lain. Formula F1 kurang disukai karena memiliki after taste yang pahit. Hal ini sejalan dengan penelitian yang dilakukan oleh Widyastuti (2019) yang melakukan pembuatan biskuit dengan substitusi millet putih menghasilkan after taste yang sedikit pahit karena sisa kulit ari yang mengandung tannin pada biji millet. Formula F1 merupakan formula dengan bahan dasar $100 \%$ tepung millet, sehingga memiliki after taste sedikit pahit yang lebih kuat dibandingkan formula lainnya.

Setiap formula memiliki jumlah tepung millet putih dan MOCAF yang berbeda sehingga berpengaruh pada karakteristik soft chewy cookies yang dihasilkan. Hasil analisis statistik dengan Kruskall Wallis menunjukkan adanya perbedaan yang signifikan $(\alpha \leq 0,05)$ pada seluruh karakteristik (warna, aroma, tekstur, dan rasa). Selanjutnya, dilakukan uji Mann Whitney untuk mengetahui pasangan formula yang memiliki perbedaan signifikan pada setiap karakteristik. Formula F0 merupakan formula kontrol yang digunakan sebagai pembanding dengan formula perlakuan (F1, F2, dan F3) Tabel 2. Menunjukkan bahwa setiap formula memiliki perbedaan signifikan dalam aspek rasa, warna, aroma, tekstur dan rasa jika dibandingkan dengan formula kontrol (F0).

\section{Daya Terima Anak ASD}

Formula yang diberikan kepada anak untuk dilakukan penilaian hanya formula F1, F2, dan F3. Formula kontrol (F0) tidak diberikan kepada anak ASD karena berbasis tepung terigu mengandung gluten yang merupakan pantangan bagi anak ASD. Tabel 3. menunjukkan distribusi penerimaan anak terhadap soft chewy cookies bebas gluten dan kasein. Formula F3 merupakan formula yang paling banyak dihabiskan oleh anak ASD (80$100 \%$ bagian).

Soft chewy cookies F3 memiliki karakteristik tekstur yang soft, aroma yang harum khas cookies, warna cokelat keemasan, dan rasa yang manis

Tabel 3. Distribusi Daya Terima Anak ASD

\begin{tabular}{lccccccc}
\hline \multirow{2}{*}{ Formula } & \multicolumn{2}{c}{$\mathbf{1}$} & \multicolumn{2}{c}{$\mathbf{2}$} & \multicolumn{2}{c}{3} & \multirow{2}{*}{ Modus } \\
\cline { 2 - 7 } & $\mathbf{n}$ & $\mathbf{\%}$ & $\mathbf{n}$ & $\mathbf{\%}$ & $\mathbf{n}$ & $\mathbf{\%}$ & \\
\hline F1 & 7 & $28 \%$ & 11 & $44 \%$ & 7 & $28 \%$ & 2 \\
F2 & 3 & $12 \%$ & 14 & $56 \%$ & 8 & $32 \%$ & 2 \\
F3 & 3 & $12 \%$ & 8 & $32 \%$ & 14 & $56 \%$ & 3 \\
\hline
\end{tabular}

Keterangan :

$1=$ anak menghabiskan $0-30 \%$ bagian kukis,

$2=$ anak menghabiskan $30-80 \%$ bagian kukis,

$3=$ anak menghabiskan $80-100 \%$ bagian kukis 
seperti cookies pada umumnya. Hal tersebut sesuai dengan penelitian Lazaro dkk (2017) tentang eating behavior pada anak ASD dimana anak ASD menyukai tekstur makanan yang lembut dan juga renyah, menyukai warna berdasarkan makanan yang biasa ia konsumsi, dan anak menolak makanan yang memiliki rasa raw dan aroma asing yang menyengat. Anak ASD menghabiskan bagian cookies F1 dan F2 lebih sedikit dikarenakan masih memiliki aroma dan rasa millet yang lebih pekat dan asing bagi anak.

\section{Nilai Gizi}

Nilai gizi merupakan indikator penting yang diperlukan untuk menemukan formula terbaik soft chewy cookies sebagai alternatif snack bebas gluten dan bebas kasein bagi anak ASD untuk meningkatkan asupan gizi mereka terutama kalsium yang dibutuhkan sesuai kondisi. Kecukupan kalsium pada anak usia 7-11 tahun dalam snack adalah 10-15\% dari Angka Kecukupan Gizi. Kebutuhan kalsium sehari anak usia 7-11 tahun berdasarkan AKG 2019 adalah 1000 mg. Tabel 4. menunjukkan kandungan kalsium pada formula berdasarkan Tabel Komposisi Pangan Indonesia (TKPI), analisis laboratorium, dan pemenuhan berdasarkan AKG per porsi $(60 \mathrm{~g})$ soft chewy cookies. Formula yang memenuhi persentase snack untuk anak berdasarkan perhitungan TKPI adalah formula F3. Dilakukan uji laboratorium pada formula F3 untuk mengetahui kadar kalsium berdasarkan analisis laboratorium. Hasil analisis laboratorium pada formula F3 menunjukkan bahwa kandungan kalsium lebih tinggi 27\% dibandingkan perhitungan dengan TKPI. Hal ini disebabkan karena kandungan bahan yang terdapat pada TKPI memiliki kandungan berbeda dengan bahan baku dasar yang digunakan pada proses pembuatan soft chewy cookies berdasarkan merk yang digunakan. Kandungan kalsium yang tinggi dihasilkan oleh tepung millet putih, sehingga formula $\mathrm{F} 1$ (100\% tepung millet putih) dan formula F2 (50\% tepung millet putih; $50 \%$ MOCAF) memiliki nilai kalsium lebih tinggi jika dibandingkan dengan F3 (25\% tepung millet putih; 75\% MOCAF). Seluruh formula F1, F2, dan F3 telah memenuhi Angka Kecukupan Gizi kalsium untuk snack anak dibandingkan dengan formula kontrol (F0) yang
Tabel 4. Kandungan Kalsium

\begin{tabular}{|c|c|c|c|}
\hline \multirow[b]{2}{*}{ Formula } & \multicolumn{2}{|c|}{ Kandungan kalsium } & \multirow{2}{*}{$\begin{array}{l}\text { Pemenuhan } \\
\text { AKG (7-11 } \\
\text { tahun) (\%) }\end{array}$} \\
\hline & TKPI (mg) & $\begin{array}{c}\text { Laboratorium } \\
\text { (mg) }\end{array}$ & \\
\hline F0 & 24,65 & - & 2 \\
\hline $\mathrm{F} 1$ & 284,35 & - & 28 \\
\hline F2 & 194,44 & - & 19 \\
\hline F3 & 151,15 & 176,4 & 15 \\
\hline
\end{tabular}

belum memenuhi Angka Kecukupan Gizi kalsium untuk anak.

Pengolahan bahan makanan dalam bentuk soft chewy cookies dengan mengombinasikan tepung millet putih dan MOCAF sebagai bahan pangan lokal dapat meningkatkan nilai guna bahan pangan tersebut dan dapat meningkatkan nilai gizinya dengan kandungan bebas gluten. Kombinasi MOCAF dan tepung millet putih juga dapat menghasilkan angka kalsium yang sesuai dengan AKG dan daya terima yang mampu bersaing dengan produk soft chewy cookies yang masih mengandung gluten. Kalsium dibutuhkan oleh anak terutama anak ASD yang memiliki pantangan untuk mengonsumsi produk susu dan olahannya.

\section{KESIMPULAN DAN SARAN}

Kombinasi MOCAF dan tepung millet putih berpengaruh pada daya terima soft chewy cookies. Hasil uji daya terima pada orang tua atau wali anak ASD terhadap warna, aroma, tekstur, dan rasa yang paling disukai adalah formula kontrol (F0), sedangkan formula perlakuan dengan daya terima paling tinggi untuk seluruh aspek adalah F3. Uji daya terima yang dilakukan pada anak ASD juga menunjukkan bahwa F3 merupakan formula yang paling banyak dihabiskan dan dapat diterima. Hasil analisis statistik menunjukkan bahwa F3 merupakan formula yang berbeda signifikan dengan formula kontrol (F0) pada aspek aroma dan rasa, sementara formula lain (F1 dan F2) berbeda signifikan dalam seluruh aspek (warna, tekstur, aroma, rasa) jika dibandingkan dengan F0. Nilai kalsium yang terkandung pada formula F3 merupakan nilai kalsium yang paling mendekati anjuran AKG untuk snack. Komposisi terbaik adalah formula $\mathrm{F} 3$ yang merupakan kombinasi $25 \%$ MOCAF dan $75 \%$ tepung millet putih. 
Soft chewy cookies bebas gluten dan bebas kasein kombinasi MOCAF dan tepung millet putih F3 dapat dijadikan alternatif snack untuk anak dengan Autism Spectrum Disorder (ASD).

\section{DAFTAR PUSTAKA}

Amalia, R. (2014). Perbedaan kepadatan tulang antara penderita autis dan tidak autis. Journal of Nutrition College, 3(2). 317-324. doi: HYPERLINK "https://doi.org/10.14710/jnc. v3i2.5439” 10.14710/jnc.v3i2.5439

Andarwulan, N., Kusnandar, F., \& Herawati, D. (2011). Analisis Pangan. Jakarta: Dian Rakyat.

Barbier, S. (2015). A qualitative assesment of eating behaviors in adults with autism (Thesis). Illinois State University. doi: 10.30707/ETD2015. Barbier.S

Besari, A. (2017). Substitusi keanekaragaman serealia dalam pembuatan cake bola salju. Jurnal Teknoboyo, 1(1), 1-18. doi: HYPERLINK "https://dx.doi.org/10.25139/tbo.v1i1.281" 10.25139/tbo.v1i1.281

Camelia, R. (2019). Studi kualitatif faktor yang mempengaruhi orang tua dalam pemberian makan anak autis. Jurnal Gizi Indonesia (The Indonesian Journal of Nutrition), 7(2), 99-108 doi: HYPERLINK "https://doi.org/10.14710/ jgi.7.2.99-108" 10.14710/jgi.7.2.99-108

Center for Disease Control. (2020). Community Report on Autism 2020: Autism and developmental disabilities monitoring (ADDM) Network, Retrieved from https://www.cdc. gov/ncbddd/autism/addm-community-report/ documents/addm-community-report-2020-h. pdf

Demand., Jhonson., Foldes.. (2016). Sychometric properties of the brief autism mealtime behaviors inventory. Journal Autism Dev Disord, 45(9), 2667-2673. doi: HYPERLINK "https://dx.doi. org/10.1007\%2Fs10803-015-2435-4" 10.1007/ s10803-015-2435-4

Gobel, V., Naiu, A. S., \& Yusuf, N. (2016). Formulasi cookies udang rebon. Jurnal Ilmiah Perikanan dan Kelautan, 4, 107-112. doi: HYPERLINK "https://doi.org/10.37905/. v4i4.5070" 10.37905/.v4i4.5070

Hendrayati, Theresia, D., \& Nursalim. (2020). Karakteristik dan mutu organoleptik fish crackers snack food. Media Gizi Pangan, 27(1), 61-69. doi: 10.32382/mgp.v27i1.1529
Izzah, A., Fatmaningrum, W., \& Roedi, I. (2020). Perbedaan gejala pada anak autis yang diet bebas gluten dan kasein dengan yang tidak diet di Surabaya. Amerta Nutrition, 4(1), 36-42.

Julia. (2013). Julia Album: Soft and chewy chocolate chip cookies. Retrieved from https:// juliasalbum.com/soft-and-chewy-chocolatechip-cookies-recipe/

Kementerian Kesehatan Republik Indonesia. (2012). Profil Kesehatan Indonesia 2011. Jakarta: Kementerian Kesehatan RI.

Kementerian Kesehatan Republik Indonesia. (2016). Kenali dan deteksi dini individu dengan spektrum autisme melalui pendekatan keluarga untuk tingkatkan kualitas hidupnya. Jakarta : Direktorat Kesehatan Keluarga Kementerian Republik Indonesia. Retrieved from http://kesga. kemkes.go.id/berita-lengkap.php?id=11-

Kementerian Kesehatan Republik Indonesia. (2019). Angka Kecukupan Gizi (AKG). Jakarta: Kementerian Kesehatan Republik Indonesia.

Lazaro, Cristiane P., Ponde, Milena P. (2017). Narratives of mother of children with autism spectrum disorders: focus on eating behavior. Trends in Psychiatry and Psychotheraphy Journal, 39(3), 4-11. doi: 10.1590/2237-60892017-0004"

Maenner, M., Shaw, K., \& Baio, J. (2020). Prevalence of autism spectrum disorder among children aged 8 years - autism and developmental disabilities monitorin network, 11 Sites, United States, 2016. MMWR Surveill Summ, 69, 1-12. doi: 10.15585/mmwr.ss6904a1

Moore E, Crook T, James J, Gonzales D, Hakkak R (2012). Nutrient intake among children with autism. Journal Nutrition Disorders \& Therapy, 2(3), 1-3. doi:10.4172/2161-0509.1000115

Prabowo, B. (2010). Kajian Sifat Fisikokimia Tepung Millet Kuning dan Tepung Millet Merah (Skripsi). Universitas Negeri Surakarta, Surakarta.

Pratiwi, RA. Dieny, FF (2014). Hubungan Skor Frekuensi Diet Bebas Gluten Bebas Kasein dengan Skor Perilaku Autis. Journal of Nutrition College, 3(1), 34-42. doi: 10.14710/jnc. v3i1.4525

Simpson, B. (2012). Food Biochemistry and Food Processing (Second Edition). Oxford: John Wiley \& Sons, Inc.

Subandoro, R., Basito, A. (2013). Pemanfaatan Tepung Millet Kuning dan Tepung Ubi Jalar Kuning sebagai Subtitusi Tepung Terigu dalam Pembuatan Cookies Terhadap Karakteristik 
Organoleptik dan Fisikokimia. Jurnal Teknosains Pangan, 2(4), 68-74.

WHO. (2019). Autism Spectrum Disorder. Diakses dari https://www.who.int/ news-room/factheets/detail/autism-spectrum-disorders
Widyastuti, R. (2019). Karakteristik biskuit tersubstitusi tepung millet. Jurnal Ilmu-Ilmu Pertanian, 3(2), 99-101. doi: 10.32585/ags. v3i2.544 